\title{
Correction to: Adapting inpatient addiction medicine consult services during the COVID-19 pandemic
}

Miriam T. H. Harris ${ }^{1,2^{*}} \mathbb{D}$, Alyssa Peterkin ${ }^{1,2}$, Paxton Bach ${ }^{3,4}$, Honora Englander $^{5}$, Emily Lapidus ${ }^{1}$, Theresa Rolley ${ }^{1}$, Melissa B. Weimer ${ }^{6}$ and Zoe M. Weinstein ${ }^{1,2}$

\section{Correction to: Addict Sci Clin Pract (2021) 16:13 https://doi.org/10.1186/s13722-021-00221- \\ 1}

In the original publication of this article [1], the author noticed that the title of Table 1 is incorrect and the format of Table 1 also has problem, the correct Table 1 is given below. The original publication has been corrected.

*Correspondence: Miriam.Harris@bmc.org

${ }^{2}$ Clinical Addiction Research and Education (CARE) Unit, Section of General Internal Medicine, Department of Medicine, Boston University

School of Medicine and Boston Medical Center, 801 Massachusetts Avenue, Second Floor, Boston, MA 02118, USA

Full list of author information is available at the end of the article

(c) The Author(s) 2021. This article is licensed under a Creative Commons Attribution 4.0 International License, which permits use, sharing, adaptation, distribution and reproduction in any medium or format, as long as you give appropriate credit to the original author(s) and the source, provide a link to the Creative Commons licence, and indicate if changes were made. The images or other third party material in this article are included in the article's Creative Commons licence, unless indicated otherwise in a credit line to the material. If material is not included in the article's Creative Commons licence and your intended use is not permitted by statutory regulation or exceeds the permitted use, you will need to obtain permission directly from the copyright holder. To view a copy of this licence, visit http://creativeco mmons.org/licenses/by/4.0/. The Creative Commons Public Domain Dedication waiver (http://creativecommons.org/publicdomain/ zero/1.0/) applies to the data made available in this article, unless otherwise stated in a credit line to the data. 
Table 1 Addiction consult service COVID-19 adaptations

\begin{tabular}{|c|c|c|c|c|}
\hline Institutional ACS Locations & St Paul's, Vancouver & OHSU, Portland & BMC, Boston & YNHH, New Haven \\
\hline ACS adaptation timing & $03 / 2020^{*}$ & $03 / 2020^{*}$ & $03 / 2020^{*}$ & $03 / 2020^{*}$ \\
\hline \multicolumn{5}{|l|}{ System/procedural adaptations } \\
\hline Shifted to predominately telemedicine visits & & $\nabla$ & $\nabla$ & $\nabla$ \\
\hline Proactive use of EMR to find new consults & & & 甲 & 甲 \\
\hline $\begin{array}{l}\text { Increased coordination and communication with bedside } \\
\text { nursing and primary teams }\end{array}$ & 曰 & $\nabla$ & 甲 & 田 \\
\hline $\begin{array}{l}\text { Reference guide, electronic catalogue, and EMR template } \\
\text { development }\end{array}$ & & & & $\square$ \\
\hline ACS led regional SUD COVID-19 response initiatives & & $\nabla$ & & \\
\hline Supported SUD management in COVID-19 Isolation Units & $\nabla$ & & $\square$ & $\square$ \\
\hline Telemedicine billing expansion to the hospital setting & & 甲 & $\square$ & $\nabla$ \\
\hline \multicolumn{5}{|l|}{ Treatment adaptations } \\
\hline Longer Buprenorphine prescriptions & $\nabla$ & $\nabla$ & $\square$ & $\square$ \\
\hline Prioritized buprenorphine due to telemedicine access & & $\nabla$ & & \\
\hline Outpatient benzodiazepine tapers for alcohol withdrawal & $\square$ & $\square$ & $\square$ & $\nabla$ \\
\hline Increased hospital peer and social work in-reach & & & $\square$ & \\
\hline \multicolumn{5}{|l|}{ Harm reduction adaptations } \\
\hline COVID-19 specific harm reduction counseling & $\square$ & $\nabla$ & $\square$ & $\nabla$ \\
\hline $\begin{array}{l}\text { Prescribing of pharmaceutical alternatives to illicit } \\
\text { substances ("safer supply") }\end{array}$ & $\square$ & & & \\
\hline Connection to virtual supervision methods & 田 & & & \\
\hline \multicolumn{5}{|l|}{ Discharge planning adaptations } \\
\hline Coordination with COVID-19 isolation and recovery units & $\square$ & & $\square$ & $\square$ \\
\hline Increased outreach post discharge & & $\nabla$ & $\nabla$ & $\nabla$ \\
\hline Increased connection with community outreach teams & $\square$ & & & \\
\hline Enhanced ability to distribute prepaid mobile phones & & $\nabla$ & $\square$ & \\
\hline
\end{tabular}

COVID-19 Novel Coronavirus Disease 2019, ACS addiction consult service, OHSU Oregon Health \& Sciences University, BMC Boston Medical Center, YNHH Yale New Haven, EMR electronic medical record, SUD substance use disorder

* Changes that were instituted starting in March have been dynamic based on local case rates and guidance from local hospital leadership and public health departments

\section{Author details}

'Grayken Center for Addiction, Boston Medical Center, Boston, MA, USA. ${ }^{2}$ Clinical Addiction Research and Education (CARE) Unit, Section of General Internal Medicine, Department of Medicine, Boston University School of Medicine and Boston Medical Center, 801 Massachusetts Avenue, Second Floor, Boston, MA 02118, USA. ${ }^{3}$ British Columbia Centre On Substance Use, St Paul's Hospital, Vancouver, BC, Canada. ${ }^{4}$ Department of Medicine, University of British Columbia, Vancouver, BC, Canada. ${ }^{5}$ Division of Hospital Medicine, Department of Medicine, Oregon Health and Science University, Portland, OR, USA. 'Program in Addiction Medicine, Department of Medicine, Yale School of Medicine, New Haven, CT, USA.

Published online: 28 April 2021

\section{Reference}

1. Harris MTH, Peterkin A, Bach P, Englander H, Lapidus E, Rolley T, Weimer MB, Weinstein ZM. Adapting inpatient addiction medicine consult services during the COVID-19 pandemic. Addict Sci Clin Pract. 2021;16:13. https://doi.org/10.1186/s13722-021-00221-1.

\section{Publisher's Note}

Springer Nature remains neutral with regard to jurisdictional claims in published maps and institutional affiliations. 